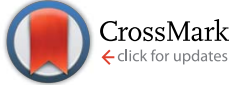

Cite this: RSC Adv., 2017, 7, 9579

\title{
The impact of an extended nucleobase-2'- deoxyribose linker in the biophysical and biological properties of oligonucleotides $\dagger$
}

\author{
Alejandro Carnero, $\ddagger^{\mathrm{a}}$ Sónia Pérez-Rentero, $\$^{\mathrm{bc}}$ Adele Alagia, ${ }^{\mathrm{bc}}$ Anna Aviñó, ${ }^{\mathrm{bc}}$ \\ Yogesh S. Sanghvi, ${ }^{d}$ Susana Fernández, ${ }^{a}$ Miguel Ferrero*a and Ramon Eritja*bc
}

\begin{abstract}
Interest in artificial DNA mimetics has been triggered by the widespread applications of nucleic acids as they are useful tools for modulation of the biophysical and biological properties of oligonucleotides. In this article, we describe the synthesis and properties of a novel thymine derivative ( $T^{*}$ ) containing an extended linker between the thymine nucleobase and the $2^{\prime}$-deoxyribose moiety. The modified $2^{\prime}$ deoxyribosyl derivative was prepared via coupling of a functionalized nucleobase to the amino group of 1-aminomethyl-2-deoxyribose, which was synthesized starting from an easily accessible cyano sugar available on a large-scale. Corresponding phosphoramidite and succinyl derivatives have also been incorporated into oligonucleotides at predetermined sites and defined internucleotidic motifs using the solid-phase synthesis approach. This derivative pairs equally well with adenine and guanine and it can be safely introduced at the $3^{\prime}$-end of the siRNAs to generate potent inhibitors of gene expression by the RNA interference mechanism.
\end{abstract}

Received 15th November 2016 Accepted 27th January 2017

DOI: 10.1039/c6ra26852h

rsc.li/rsc-advances
(HNA), ${ }^{6}$ bicyclo, ${ }^{7}$ arabino (ANA) ${ }^{8,9}$ and fluoroarabino (FANA) $)^{\mathbf{8 , 9}}$ nucleic acids. The discovery of RNA interference mechanism provide also an opportunity to the design of novel nucleic acid derivatives with more structural flexibility such as unlocked (UNA) ${ }^{10}$ acyclic threoninol (aTNA), ${ }^{11}$ and serinol (SNA) ${ }^{12}$ nucleic acid derivatives. The presence of these compounds in selected positions of siRNA has shown to improve the silencing properties $^{12,13}$ as well as diminish off-target effects. ${ }^{14}$ For all these reasons research on flexible nucleoside analogues has generated an increasing interest for the structural and biological impact of these nucleic acid derivatives. Most of the flexible nucleoside derivatives have been generated by substituting the ribose moiety by an acyclic derivative. In addition, the synthesis and hybridization properties of the methyl and ethyl thymine alkane 2 -deoxyribosides (B in Chart 1 ) have been described. ${ }^{\mathbf{1 5 , 1 6}}$ These compounds were designed to be used in triplex formation to stabilize triplexes with short polypurine-polypyrimidine tracts as they may be used as a wild card in the interruptions of the polypurine-polypyrimidine tracts by alternate binding. ${ }^{\mathbf{1 6}, 17}$

In this communication we described the synthesis of a thymine derivative $\left(\mathrm{T}^{*}\right)$ with an extended link between the $2^{\prime}$ deoxyribose phosphate backbone and the thymine base $(\mathbf{C}$, in Chart 1). The novel $\mathrm{T}^{*}$ derivative has been prepared by the coupling of $N^{1}$-carboxymethylthymine to 1-aminomethyl-2deoxyriboside. $N^{1}$-Carboxymethylthymine is being also used in the preparation of the thymine derivative of PNA, aTNA and SNA. The hybridization properties of modified DNA duplexes and the silencing properties of siRNAs carrying this derivative at the $3^{\prime}$-end of siRNA are described. 


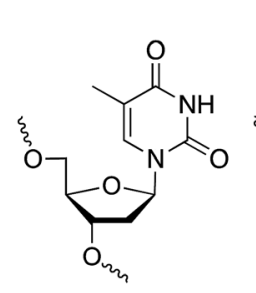

A

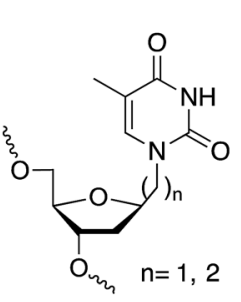

B

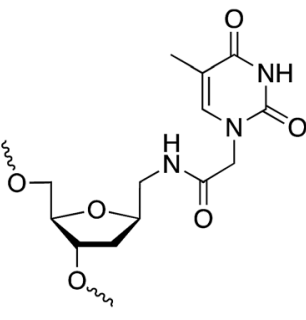

C
Chart 1 Structure of DNA (A) and DNA mimetics (B and C) with extended links between nucleobase and $2^{\prime}$-deoxyribose moiety. (A) Unmodified thymidine; (B) methyl and ethyl derivatives described in ref. 15 and 16; and (C) N-methylacetamido derivative described in this work.

\section{Results and discussion}

\section{Synthesis of the extended $\mathrm{T}^{*}$ derivative monomer unit}

For the preparation of thymine derivative we designed a strategy starting with cyano sugar $\mathbf{1}$ (Scheme 1), which is easily accessible on large-scale. ${ }^{18}$ Reduction of the cyano group using hydrogen and RANEY ${ }^{\circledR}$ nickel catalyst furnished amino compound 2. Treatment of the later with $N^{1}$-carboxymethylthymine and propylphosphonic anhydride afforded 3 in $65 \%$ yield. Removal of the toluoyl protecting groups in 3 by reaction with $\mathrm{KOH}$ in $\mathrm{EtOH}-\mathrm{H}_{2} \mathrm{O}$ followed by neutralization with Dowex 50WX8 gave the diol 4 in excellent yield. Next, protection of the primary alcohol with 4,4'-dimethoxytrityl chloride in the presence of $\mathrm{Et}_{3} \mathrm{~N}$ and pyridine, producing the key intermediate $\mathbf{5}$, which permits an easy access to the required monomer precursor for oligonucleotide solid-phase synthesis.

Phosphitylation of DMT-protected compound 5 with 2-cyanoethoxy- $N, N$-diisopropylaminochlorophosphine in the presence of diisopropylethylamine gave the desired phosphoramidite derivative 6 in $85 \%$ yield. This phosphoramidite was used for the introduction of $\mathrm{T}^{*}$ at an internal position during oligonucleotide synthesis. To introduce the $\mathrm{T}^{*}$ modification at the $3^{\prime}$-end of siRNAs, the derivatized support precursor 8 was prepared by

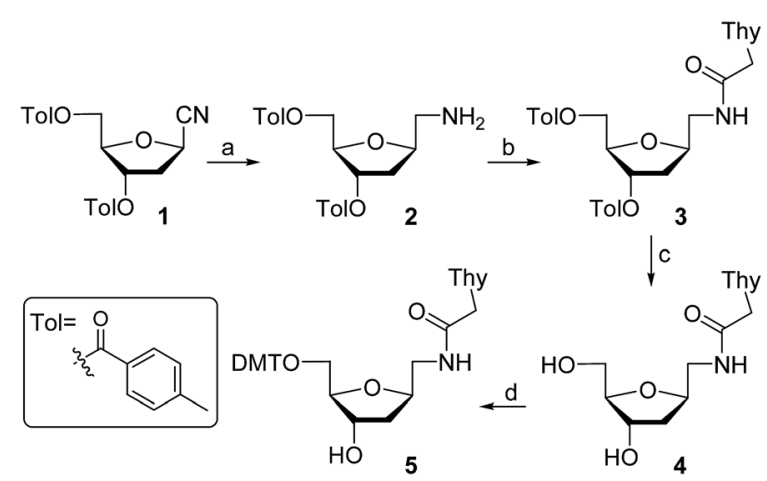

Scheme 1 Synthesis of $5^{\prime}$-DMT-T* nucleoside precursor. Reagents and conditions: (a) $\mathrm{H}_{2}$, RANEY® $\mathrm{Ni}, \mathrm{MeOH}, \mathrm{rt}, 12 \mathrm{~h}$ (70\%); (b) Thy$\mathrm{CH}_{2} \mathrm{CO}_{2} \mathrm{H}$, propylphosphonic anhydride, ${ }^{\mathrm{i}} \mathrm{Pr}_{2} \mathrm{NEt}, \mathrm{DMF}, \mathrm{rt}, 5 \mathrm{~h}(65 \%)$; (c) $\mathrm{KOH}, \mathrm{EtOH}-\mathrm{H}_{2} \mathrm{O}, \mathrm{rt}, 30 \mathrm{~min}$ (95\%); (d) $\mathrm{DMTCl}, \mathrm{Et}_{3} \mathrm{~N}, \mathrm{Py}, 45^{\circ} \mathrm{C}, 5 \mathrm{~h}$ (69\%). conversion of 5 to the corresponding hemisuccinate 7 via DMAP catalyzed reaction with succinic anhydride (Scheme 2).

This hemisuccinate was then used to functionalize controlled pore glass solid-support, yielding derivative 8 .

\section{Synthesis of DNA oligonucleotides}

Oligodeoxynucleotides used in this study are summarized in Table 1. Modified oligonucleotides $15 \mathrm{Mer}_{-} \mathrm{T}^{*}(01),(02)$ and (03) were assembled by solid-phase on a DNA synthesizer using polystyrene support. In all cases the coupling yields of the modified phosphoramidite were similar to standard phosphoramidites yielding the desired oligonucleotides that were purified by HPLC and characterized by MALDI-TOF mass spectrometry.

\section{Denaturation studies on DNA oligonucleotides}

The effect of the modification $\left(\mathrm{T}^{*}\right)$ in the duplex stability was analyzed by recording the denaturation curves by UV-visible spectroscopy (Fig. 1).

Three modified oligonucleotides [15Mer_T*(01), one $\mathrm{T}^{*}$ modification; 15Mer_T*(02), two $\mathrm{T}^{*}$ modifications at different positions of the sequence; and $15 \mathrm{Mer}_{-} \mathrm{T}^{*}(03)$, two consecutive $\mathrm{T}^{*}$ modifications] were annealed with their corresponding complementary sequence (15MerA, Fig. 1). The results are summarized in Table 2 and represented in Fig. 1. A single modification caused a decrease of $12.5{ }^{\circ} \mathrm{C}$ in the $T_{\mathrm{m}}$. Two consecutive modifications caused a lower destabilization $\left(-15^{\circ} \mathrm{C}\right)$ than two $\mathrm{T}^{*}$ modifications located in different places $\left(-30.8^{\circ} \mathrm{C}\right)$. These values are in agreement to the values found for the thymine alkane 2 -deoxyribosides developed by Beaucage

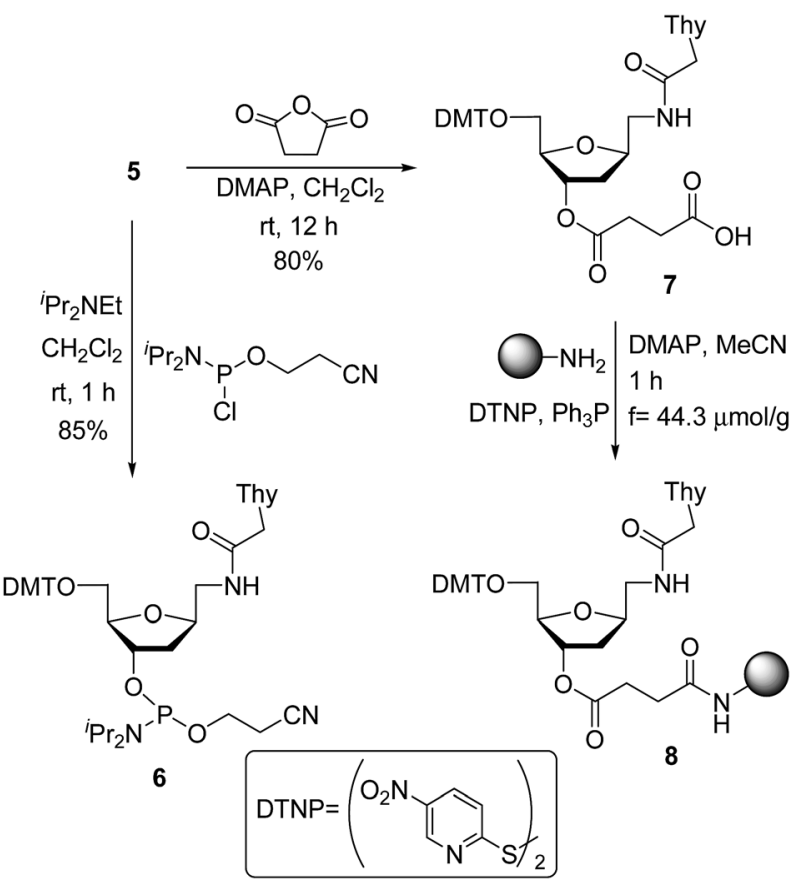

Scheme 2 Synthesis of modified nucleoside monomers: phosphoramidite 6 and support-linked hemisuccinate 8. 
Table 1 Oligonucleotide sequences used in this study

\begin{tabular}{llll}
\hline Code & Sequences $\left(5^{\prime} \rightarrow 3^{\prime}\right)$ & MW (calcd) & MW $^{a}$ (found) \\
\hline 15 Mer_T*(01) & d(TAG AGG CT*C CAT TGC) & 4639.1 & 4639.2 \\
15 Mer_T*(02) & d(TAG AGG CT*C CAT* TGC) & 4710.2 & 4711.6 \\
15 Mer_T*(03) & d(TAG AGG CTC CAT* T*GC) & 4710.2 & 4709.6 \\
15 Mer_UnMod & d(TAG AGG CTC CAT TGC) & n.d. & n.d. \\
15MerA & d(GCA ATG GAG CCT CTA) & n.d. & n.d. \\
15 MerG & d(GCA ATG GGG CCT CTA) & n.d. & n.d. \\
15 MerC & d(GCA ATG GCG CCT CTA) & n.d. & n.d.
\end{tabular}

${ }^{a}$ Using MALDI-TOF mass spectrometry. n.d. not determined, since the unmodified oligonucleotides were purchased.

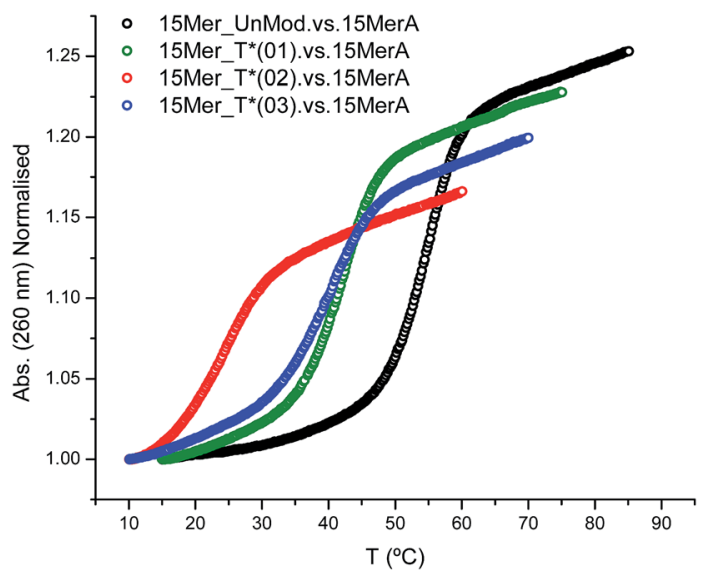

Fig. 1 Melting curves of modified oligonucleotides with 15MerA.

and co-workers. ${ }^{15,16}$ These authors have used a duplex consisting of 24 bases, with two modifications in alternate positions in the middle of the sequence. They observed a decrease of 10 degrees in the $T_{\mathrm{m}}$ for the methyl-T derivative and a decrease of 5 degrees for the ethyl-T derivative.

In addition, we studied the base paring properties of the modified $\mathrm{T}^{*}$ evaluating the melting temperatures of the duplexes carrying all the possible base pairs. The denaturation curves are shown in Fig. 2 and the results are summarized in Table 3.

As expected, when a mispair was introduced in the unmodified duplex a decrease in the thermal stability was observed. Surprisingly with the $15 \mathrm{Mer}_{-} \mathrm{T}^{*}(01)$ series, we found that the

Table $2 T_{\mathrm{m}}$ and $\Delta G^{\circ}$ values at $298 \mathrm{~K}$ obtained for the modified sequences $^{a}$

\begin{tabular}{lllll}
\hline Duplex & $\begin{array}{l}T_{\mathrm{m}} \\
\left({ }^{\circ} \mathrm{C}\right)\end{array}$ & $\begin{array}{l}\Delta T_{\mathrm{m}} \\
\left({ }^{\circ} \mathrm{C}\right)\end{array}$ & $\begin{array}{l}\Delta G^{\circ} \\
\left(\mathrm{kcal} \mathrm{mol}^{-1}\right)\end{array}$ & $\begin{array}{l}\Delta \Delta G^{\circ} \\
\left(\mathrm{kcal} \mathrm{mol}^{-1}\right)\end{array}$ \\
\hline 15MerA. vs. 15Mer_UnMod & 54.2 & - & -13.9 & - \\
15MerA. vs. 15Mer_T*(01) & 41.7 & -12.5 & -9.3 & -4.6 \\
15MerA. vs. 15Mer_T*(02) & 23.4 & -30.8 & -4.6 & -9.3 \\
15MerA. vs. 15Mer_T*(03) & 39.2 & -15.0 & -8.3 & -5.6
\end{tabular}

${ }^{a} 50 \mathrm{mM} \mathrm{NaCl}$ and $10 \mathrm{mM}$ sodium phosphate buffer $\mathrm{pH}$ 7.0.
G:T* base pair had the highest $T_{\mathrm{m}}\left(\sim 1.5^{\circ} \mathrm{C}\right.$ than the A:T* base pair). The insertion of a $-\mathrm{CH}_{2} \mathrm{CONHCH}_{2}$ - tether between the carbohydrate and the nucleobase in general is not favorable for a good alignment of the nucleobases to form stable WatsonCrick base pairs, but in the case of the G:T* base pair the tether may allow the formation of a G:T* wobble base pair (Chart 2).

The $\mathrm{T}^{*}$ modification loses the ability of distinguishing between $\mathrm{A}$ and $\mathrm{G}$ as the melting temperatures of the duplexes carrying $A: T^{*}$ and $\mathrm{G}: \mathrm{T}^{*}$ base pairs have similar melting temperatures. As a matter of fact, the duplex carrying the G:T* base pair has a higher $T_{\mathrm{m}}$ than the duplex carrying A:T* base pair $\left(1.5{ }^{\circ} \mathrm{C}\right.$ higher $)$. This effect has not been described previously. The closest system with $T_{\mathrm{m}}$ values of all the mispairs is

A)
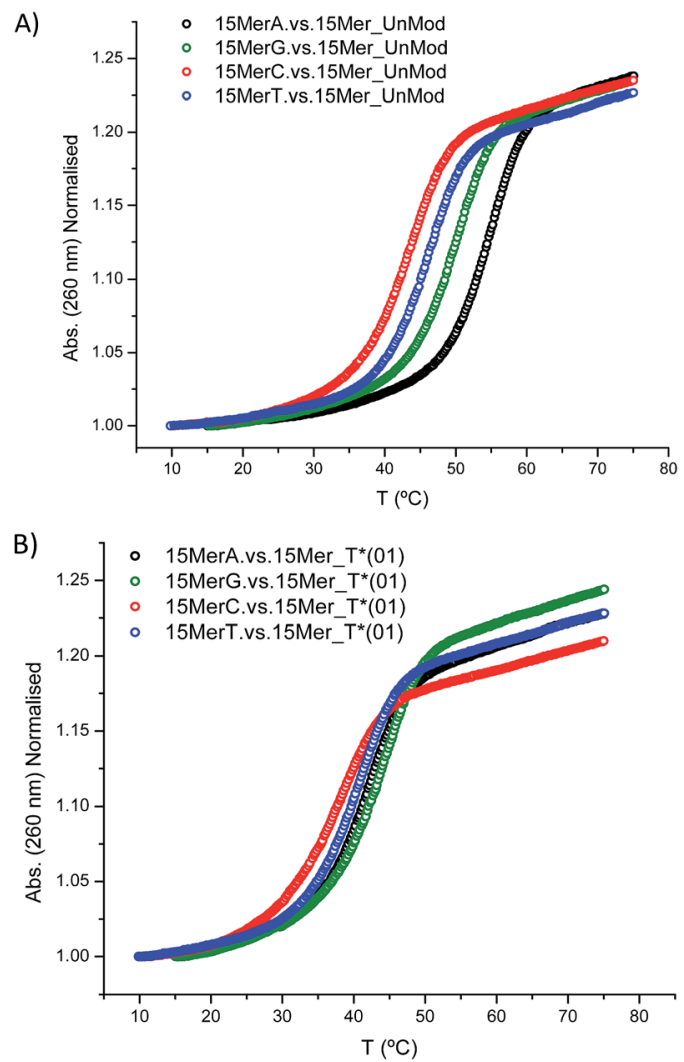

Fig. 2 Melting curves of: (A) 15Mer_UnMod vs. 15MerX; (B) 15Mer_T*(01) vs. 15MerX. Note: $X=A, G, C, T$. 
Table $3 T_{\mathrm{m}}$ and $\Delta G^{\circ}$ values at $298 \mathrm{~K}$ obtained for mispaired duplexes ${ }^{a}$

\begin{tabular}{|c|c|c|c|c|c|c|c|}
\hline Duplex & $\begin{array}{l}\text { Base pair } \\
\mathrm{X}: \mathrm{Y}\end{array}$ & $\begin{array}{l}T_{\mathrm{m}} \\
\left({ }^{\circ} \mathrm{C}\right)\end{array}$ & $\begin{array}{l}\Delta T_{\mathrm{m}}(\mathbf{1}) \\
\left({ }^{\circ} \mathrm{C}\right)\end{array}$ & $\begin{array}{l}\Delta T_{\mathrm{m}}(2) \\
\left({ }^{\circ} \mathrm{C}\right)\end{array}$ & $\begin{array}{l}\Delta G^{\circ} \\
\left(\mathrm{kcal} \mathrm{mol}^{-1}\right)\end{array}$ & $\begin{array}{l}\Delta \Delta G^{\circ} \\
\text { (1) }\left(\mathrm{kcal} \mathrm{mol}^{-1}\right)\end{array}$ & $\begin{array}{l}\Delta \Delta G^{\circ} \\
\text { (2) }\left(\mathrm{kcal} \mathrm{mol}^{-1}\right)\end{array}$ \\
\hline 15MerA. vs. 15Mer_UnMod & $\mathrm{A}: \mathrm{T}$ & 54.2 & - & - & -13.9 & - & - \\
\hline 15MerC. vs. 15Mer_UnMod & $\mathrm{C}: \mathrm{T}$ & 42.9 & -11.3 & - & -9.5 & -4.4 & - \\
\hline 15MerT. vs. 15Mer_UnMod & $\mathrm{T}: \mathrm{T}$ & 45.3 & -8.9 & - & -10.4 & -3.5 & - \\
\hline 15MerA. vs. 15Mer_T*(01) & $\mathrm{A}: \mathrm{T}^{*}$ & 41.7 & - & -12.5 & -9.3 & - & -4.6 \\
\hline 15MerT. vs. 15Mer_T*(01) & $\mathrm{T}: \mathrm{T}^{*}$ & 39.8 & - & -5.5 & -8.6 & - & -1.8 \\
\hline
\end{tabular}

${ }^{a} \Delta T_{\mathrm{m}}(\mathbf{1})$ and $\Delta \Delta G^{\circ}(\mathbf{1})$ : in comparison with 15MerA. $v s$. 15Mer_UnMod; $\Delta T_{\mathrm{m}}$ (2) and $\Delta \Delta G^{\circ}$ (2): in comparison with the corresponding unmodified duplex.

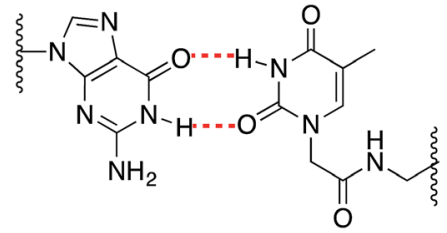

Chart 2 Schematic representation of a G:T* wobble base pair.

the melting study of $\mathrm{L}$-threoninol- $\mathrm{T}\left(\mathrm{T}^{\mathrm{L}}\right)$ in a RNA:RNA duplex ${ }^{\mathbf{1 4}}$ and in this context there was a decrease on $T_{\mathrm{m}}$ for G: $\mathrm{T}^{\mathrm{L}}$ modified base pair $\left(0.7^{\circ} \mathrm{C}\right)$ compared with $\mathrm{A}: \mathrm{T}^{\mathrm{L}}$ modified base pair.

\section{Preparation of RNA modified oligonucleotides}

Next, we have prepared several RNA strands carrying either two natural thymidine or two modified $\mathrm{T}^{*}$ units at $3^{\prime}$-end (Table 4). All possible complementary RNA strands were formed (Table 5), and the resulted siRNA duplexes were used to target the Renilla luciferase gene as described. ${ }^{13}$

In order to appraise the potency of modified siRNA molecules, we have performed dose-response experiments in HeLa cells. Briefly, we co-transfected Psi-CHECK2 vector with decreasing concentrations of siRNA duplexes $(1 ; 0.3 ; 0.16 ; 0.06$; $0.016 ; 0.008 ; 0.002 \mathrm{nM})$ and after $24 \mathrm{~h}$ of incubation, we measured the expression of Renilla protein.

As shown in Table 5 and Fig. 3 all modified siRNAs were strong inhibitors of Renilla luciferase. Notably, the ST3 siRNA, modified at sense overhang, is significantly more potent compared to unmodified siRNA (WT). The activity of ST2 siRNA, even if retained good inhibitory properties, is comparable to WT

Table 4 Sequences and mass spectrometry analysis of RNA oligonucleotides

\begin{tabular}{llll}
\hline Code & Sequences $\left(5^{\prime} \rightarrow 3^{\prime}\right)$ & $\mathrm{MW}($ calcd) & $\mathrm{MW}^{a}$ (found) \\
\hline ASwt & UUUUUCUCCUUCUUCAGAUTT & 6439 & 6434 \\
SSwt & AUCUGAAGAAGGAGAAAAATT & $6829\left(\mathrm{Na}^{+}\right)$ & $6829\left(\mathrm{Na}^{+}\right)$ \\
ASmd & UUUUUCUCCUUCUUCAGAUT*T* & 6581 & 6580 \\
SSmd & AUCUGAAGAAGGAGAAAAAT* ${ }^{*}$ & 6948 & 6946
\end{tabular}

${ }^{a}$ Using MALDI-TOF mass spectrometry.
siRNA. The different silencing activities between ST2 and ST3 siRNAs basically depend on overhang recognition by the Ago2 protein, the core effectors of the RNAi pathway. The better the interaction between the Ago2's Paz domain and the overhang, the stronger is the inhibition on the target mRNA. Unlike the acyclic threoninol-T modification (structurally close to considered $\mathrm{T}^{*}$ modification), ${ }^{\mathbf{1 3}}$ which exert its best performance when placed at antisense overhang, the $\mathrm{T}^{*}$ modification yielded more active siRNA when introduced at sense overhang (ST3). The equivalent potency between antisense modified (ST2) and

Table 5 Sequences of unmodified and modified siRNAs targeting the Renilla luciferase mRNA and inhibition concentration $\left({ } C_{50}\right)$ values

\begin{tabular}{|c|c|c|c|}
\hline siRNA & Code & Sequences & $\mathrm{IC}_{50}(\mathrm{pM} \pm \mathrm{SD})$ \\
\hline WT & $\begin{array}{l}\text { SSwt } \\
\text { ASwt }\end{array}$ & $\begin{array}{l}\text { TTAAAAAGAGGAAGAAGUCUA-5' } \\
5^{\prime} \text {-UUUUUCUCCUUCUUCAGAUTT }\end{array}$ & $6.3 \pm 1.8$ \\
\hline ST2 & $\begin{array}{l}\text { SSwt } \\
\text { ASmd }\end{array}$ & $\begin{array}{l}\text { TTAAAAAGAGGAAGAAGUCUA-5' } \\
5^{\prime} \text {-UUUUUCUCCUUCUUCAGAUT*T* }{ }^{*}\end{array}$ & $6.1 \pm 2.6$ \\
\hline ST3 & $\begin{array}{l}\text { SSmd } \\
\text { ASwt }\end{array}$ & $\begin{array}{l}\mathrm{T}^{*} \mathrm{~T}^{* A A A A A G A G G A A G A A G U C U A-5^{\prime}} \\
5^{\prime} \text {-UUUUUCUCCUUCUUCAGAUTT }\end{array}$ & $3.2 \pm 1.3$ \\
\hline ST4 & $\begin{array}{l}\text { SSmd } \\
\text { ASmd }\end{array}$ & $\begin{array}{l}\mathrm{T}^{*} \mathrm{~T}^{*} \text { AAAAAGAGGAAGAAGUCUA- } 5^{\prime} \\
5^{\prime} \text {-UUUUUCUCCUUCUUCAGAUT }{ }^{*} \mathrm{~T}^{*}\end{array}$ & $5.0 \pm 2.9$ \\
\hline
\end{tabular}

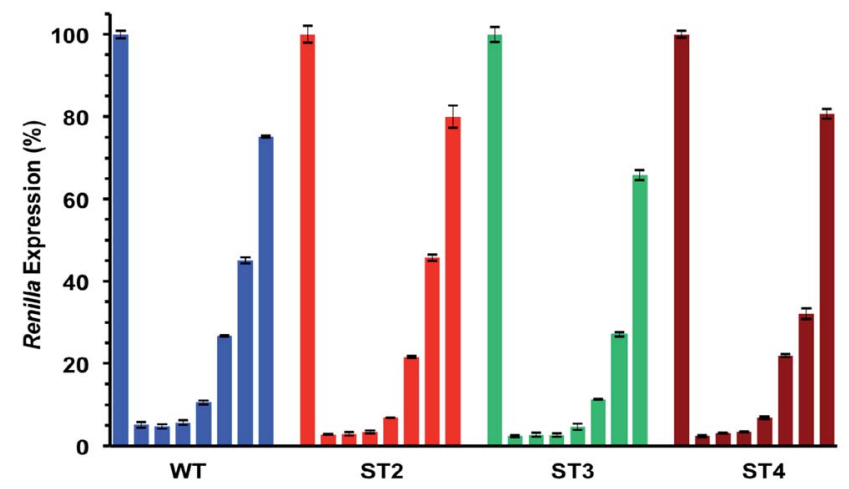

Fig. $3 \quad I_{50}$ assessments of siRNA molecules using luciferase assay. Dose-response curves of unmodified siRNA (WT), and T*-modified (ST2, ST3, ST4) siRNAs. Decreasing concentrations (nM): control; 1; 0.3 ; 0.16; 0.06; 0.016; 0.008; 0.002. $n=3 \pm$ SD. For experimental conditions see the Experimental section. 


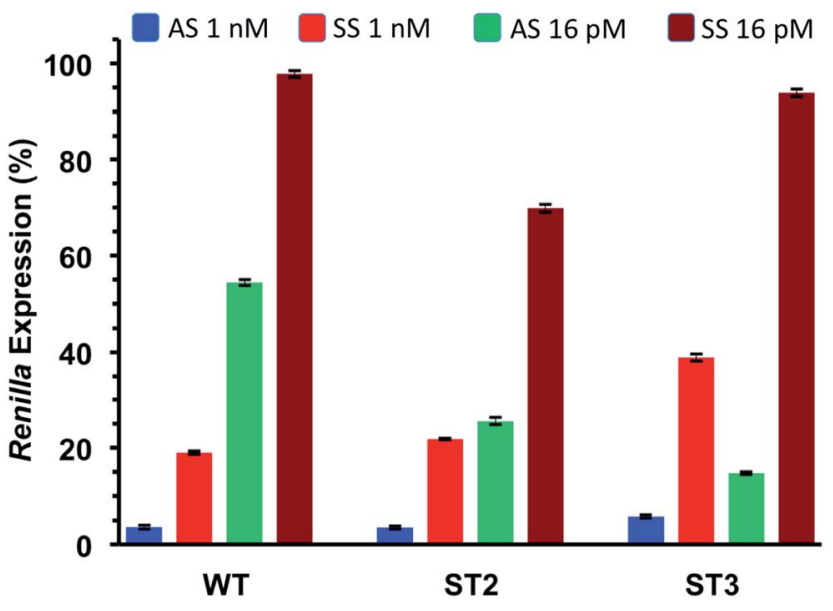

Fig. 4 ON-/OFF-target silencing of $T^{*}$-modified siRNAs at final concentrations of $1 \mathrm{nM}$ and $16 \mathrm{pM}, \mathrm{WT}, \mathrm{ST} 2$ and ST3 siRNAs were cotransfected with psiCHECK2 sensors (AS and SS) in HeLa cells. $n=3 \pm$ SD. ST2 siRNA carries the T* modification at the antisense strand and ST3 at the sense strand.

unmodified (WT) siRNAs suggested that the modification is as well recognized as natural thymidine by the PAZ domain. The application of siRNA-based therapeutics is hampered by their numerous OFF-target effects. One of the most relevant comes from the wrong strand selection by the RISC. Since the strand loading was demonstrated to rely on thermodynamic stability of the two ends of siRNA duplex, we thought to compared the ON-/ OFF-target activities of the $\mathrm{T}^{*}$ modified siRNAs (ST2 and ST3) with the unmodified siRNA (WT). We used two different psicheck 2 reporters, one codifying for an mRNA complementary to antisense strand (AS) and one to the sense strand (SS).

Thus, we co-transfected HeLa cells with either AS or SS vector and two siRNA concentrations ( $1 \mathrm{nM}$ and $16 \mathrm{pM}$ ). After $24 \mathrm{~h}$ incubation we measured the levels of Renilla expression by Dual-luciferase assay system. Such study, assessing the silencing abilities of each strand independently, provided rapid and reliable estimation of the efficiencies of siRNA-mediated inhibition for both the antisense (AS) and sense strand (SS).

As depicted in Fig. 4, all considered siRNAs (WT, ST2 and ST3) at the highest dose (1 nM) disclosed poor balance between ON-/OFF-target activities. However, the best performance owns to the ST3 siRNA.

At the lowest dose transfected (16 pM), the ST3 siRNA is practically inactive towards the off-target mRNA (SS) while retaining $80 \%$ inhibition of the on-target mRNA (AS). Taking all these results together we can conclude than the $\mathrm{T}^{*}$ modification is totally compatible with the RNA interference machinery, and it may provide higher efficiency and selectivity than unmodified siRNA when the modification is introduced at the 3 '-end of the sense strand.

\section{Conclusions}

In the present work the synthesis, binding and gene silencing properties of oligonucleotides carrying the extended nucleobase modification $\left(\mathrm{T}^{*}\right)$ are described. The novel pseudonucleoside was obtained by the coupling of an amino sugar as the glycosyl donor with $N^{1}$-carboxymethylthymine. The presence of one single modification in the middle of a DNA duplex (15Mer, low salt conditions) induces a decrease of $12.5{ }^{\circ} \mathrm{C}\left(-4.6 \mathrm{kcal} \mathrm{mol}^{-1}\right)$ in the $T_{\mathrm{m}}$. Two $\mathrm{T}^{*}$ modifications in a row are less destabilizing than separated. The $\mathrm{T}^{*}$ modification loses the ability of distinguishing between $\mathrm{A}$ and $\mathrm{G}$ as the melting temperatures of the duplexes carrying A:T* and G:T* base pairs have similar melting temperatures. The introduction of $\mathrm{T}^{*}$ at the $3^{\prime}$-end of either or both guide and passenger strand is well tolerated by the RISC machinery giving similar or better $\mathrm{IC}_{50}$ than unmodified siRNA. In the case of having the $\mathrm{T}^{*}$ modification at the passenger strand the potential off-target effects are diminished. For these reasons, the introduction of this derivative at the $3^{\prime}$-end of the sense strand generates modified siRNAs that are more potent and selective inhibitors of gene expression by the RNA interference mechanism.

\section{Experimental protocols}

\section{Synthesis of modified monomer units}

1及-Aminomethyl-1,2-dideoxy-3,5-di-O-toluoyl-d-ribose (2). A mixture of RANEY ${ }^{\circledR}$ nickel ( $\sim 100 \mathrm{mg}$, slurry in water) and cyano sugar 1 (100 mg, $0.026 \mathrm{mmol}$ ) in $\mathrm{MeOH}(3 \mathrm{~mL}$ ) was exposed to a positive pressure of hydrogen gas (balloon). The reaction was stirred vigorously overnight. The mixture was filtered on Celite, concentrated, and the crude subjected to column chromatography ( $\left.3 \% \mathrm{MeOH} / \mathrm{CH}_{2} \mathrm{Cl}_{2}\right)$ to afford 2 as yellowish viscous liquid in $70 \%$ yield. $R_{\mathrm{f}}: 0.2\left(5 \% \mathrm{MeOH} / \mathrm{CH}_{2} \mathrm{Cl}_{2}\right)$; IR ( $\left.\mathrm{NaCl}\right): \nu 3407,3055$, 2987, 1718, $1266 \mathrm{~cm}^{-1}$; ${ }^{1} \mathrm{H}$ NMR $\left(300.13 \mathrm{MHz}, \mathrm{CDCl}_{3}\right): \delta 2.15(\mathrm{~m}$, $2 \mathrm{H}, \mathrm{H} 2^{\prime}$ ), 2.38 (s, 3H, Me-Tol), 2.40 (s, 3H, Me-Tol), 2.84 (dd, 1H, $\mathrm{H6}^{\prime}, J_{\mathrm{HH}} 12.9,6.0 \mathrm{~Hz}$ ), 3.06 (overlapped, $1 \mathrm{H}, \mathrm{H6}^{\prime}$ ), 3.14 (br s, $2 \mathrm{H}$, $\left.\mathrm{NH}_{2}\right), 4.38\left(\mathrm{~m}, 2 \mathrm{H}, \mathrm{H} 4^{\prime}+\mathrm{H} 1^{\prime}\right), 4.51\left(\mathrm{~m}, 2 \mathrm{H}, \mathrm{H} 5^{\prime}\right), 5.48(\mathrm{~m}, 1 \mathrm{H}$, $\mathrm{H}^{\prime}$ ), 7.22 (2d, 4H, $\left.\mathrm{H}_{\text {ortho }}-\mathrm{Me}\right), 7.91$ (2d, $\left.4 \mathrm{H}, \mathrm{H}_{\text {ortho }}-\mathrm{CO}\right) \mathrm{ppm} ;{ }^{13} \mathrm{C}$ NMR (75.5 MHz, $\left.\mathrm{CDCl}_{3}\right)$ : $\delta 21.8\left(2 \mathrm{CH}_{3}\right), 35.5\left(\mathrm{C}^{\prime}\right), 45.0\left(\mathrm{C6}^{\prime}\right)$, $64.7\left(\mathrm{C5}^{\prime}\right), 76.9\left(\mathrm{C}^{\prime}\right), 79.5\left(\mathrm{C1}^{\prime}\right), 82.8\left(\mathrm{C}^{\prime}\right), 127.0\left(\mathrm{C}_{\text {ipso }}-\mathrm{CO}\right), 127.1$ $\left(\mathrm{C}_{\text {ipso }}-\mathrm{CO}\right), 129.27 \quad\left(2 \mathrm{C}_{\text {ortho }}-\mathrm{Me}\right), 129.30 \quad\left(2 \mathrm{C}_{\text {ortho }}-\mathrm{Me}\right), 129.8$ (4C $\left.\mathrm{C}_{\text {ortho }}-\mathrm{CO}\right), 144.0\left(\mathrm{C}_{i p s o}-\mathrm{Me}\right), 144.2\left(\mathrm{C}_{i p s o}-\mathrm{Me}\right), 166.2(C=\mathrm{O})$, $166.6(C=\mathrm{O})$ ppm; HRMS $\left(\mathrm{ESI}^{+}, \mathrm{m} / z\right)$ : calcd for $\mathrm{C}_{22} \mathrm{H}_{26} \mathrm{NO}_{5}[(\mathrm{M}+$ $\left.\mathrm{H}^{+}\right]$: 384.1805, found: 384.1808 .

1,2-Dideoxy-1 $\beta$-[ $N$-(1-thyminylacetyl)aminomethyl]-3,5-di-Otoluoyl-D-ribose (3). Amino sugar $2(50 \mathrm{mg}, 0.13 \mathrm{mmol})$ was dissolved in anhydrous DMF $(0.3 \mathrm{~mL})$ and $N^{1}$-carboxymethylthymine $(18.4 \mathrm{mg}, 0.1 \mathrm{mmol})$, propylphosphonic anhydride $(59.5 \mathrm{mg}, 0.1 \mathrm{mmol})$ and ${ }^{\mathrm{i}} \operatorname{Pr}_{2} \mathrm{NEt}(35 \mu \mathrm{L}, 0.2 \mathrm{mmol})$ were added. The mixture was stirred at room temperature for $5 \mathrm{~h}$ until complete conversion (TLC 5\% $\mathrm{MeOH} / \mathrm{CH}_{2} \mathrm{Cl}_{2}$ ) and then poured into a stirred mixture of ice-water and saturated $\mathrm{NaHCO}_{3}$ aqueous solution (7:1). The product precipitated after standing overnight in the fridge and it was collected by filtration. The crude product was purified through column chromatography $\left(2 \% \mathrm{MeOH} / \mathrm{CH}_{2} \mathrm{Cl}_{2}\right)$ to afford 3 in $65 \%$ yield. $R_{\mathrm{f}}$ : 0.32 (5\% $\mathrm{MeOH} / \mathrm{CH}_{2} \mathrm{Cl}_{2}$ ); mp: $183-184{ }^{\circ} \mathrm{C}$; IR (KBr): $\nu$ 3551, 3478, 3412, 3333, 2993, 1718, 1665, 1612, $1556 \mathrm{~cm}^{-1} ;{ }^{1} \mathrm{H}$ NMR $\left(300.13 \mathrm{MHz}, \mathrm{CDCl}_{3}\right): \delta 1.81$ (br s, $\left.1 \mathrm{H}, \mathrm{NH}\right), 1.91$ (s, 3H, Me-C5), 2.12 (m, 2H, H2'), 2.40 (s, 3H, Me-Tol), 2.41 (s, 3H, Me-Tol), 3.44 
(dt, $1 \mathrm{H}, \mathrm{H6}^{\prime}, J_{\mathrm{HH}} 14.1,3.1 \mathrm{~Hz}$ ), 3.64 (ddd, 1H, $\mathrm{H6}^{\prime}, J_{\mathrm{HH}} 13.9,7.5$, $3.8 \mathrm{~Hz}), 4.26$ (d, $\left.1 \mathrm{H}, \mathrm{H}^{\prime}, J_{\mathrm{HH}} 15.8 \mathrm{~Hz}\right), 4.35-4.48\left(\mathrm{~m}, 4 \mathrm{H}, \mathrm{H}^{\prime}+\right.$ $\left.\mathrm{H} 4^{\prime}+\mathrm{H}^{\prime}+\mathrm{H}^{\prime}\right), 4.73\left(\mathrm{dd}, 1 \mathrm{H}, \mathrm{H}^{\prime}, J_{\mathrm{HH}} 12.2,8.1 \mathrm{~Hz}\right), 5.42(\mathrm{~d}, 1 \mathrm{H}$, $\mathrm{H}^{\prime}, J_{\mathrm{HH}} 5.3 \mathrm{~Hz}$ ), 7.01 (s, 1H, H6'), 7.24 (2d, 4H, $\left.\mathrm{H}_{\text {ortho }}-\mathrm{Me}\right), 7.92$ (2d, 4H, $\mathrm{H}_{\text {ortho }} \mathrm{CO}$ ), 8.86 (br s, $\left.1 \mathrm{H}, \mathrm{NH}\right) \mathrm{ppm} ;{ }^{13} \mathrm{C}$ NMR (75.5 $\left.\mathrm{MHz}, \mathrm{CDCl}_{3}\right): \delta 12.5\left(\mathrm{CH}_{3}-\mathrm{C} 5\right), 21.9\left(2 \mathrm{CH}_{3}-\mathrm{Tol}\right), 34.3\left(\mathrm{C2}^{\prime}\right), 41.2$ $\left(\mathrm{C6}^{\prime}\right), 50.7\left(\mathrm{C}^{\prime}\right), 64.9\left(\mathrm{C5}^{\prime}\right), 77.4\left(\mathrm{C}^{\prime}\right), 78.4\left(\mathrm{C}^{\prime}\right), 83.6\left(\mathrm{C}^{\prime}\right), 110.9$

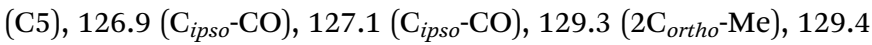

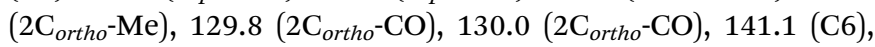
$144.4\left(2 \mathrm{C}_{i p s o}-\mathrm{Me}\right), 151.1(\mathrm{C} 2), 164.2(\mathrm{C} 4), 166.3\left(\mathrm{O}=C-\mathrm{C}^{\prime}\right), 167.2$ $(C=\mathrm{O}), 167.3 \quad(C=\mathrm{O}) \mathrm{ppm}$; HRMS $\left(\mathrm{ESI}^{+}, \mathrm{m} / \mathrm{z}\right)$ : calcd for $\mathrm{C}_{29} \mathrm{H}_{31} \mathrm{~N}_{3} \mathrm{NaO}_{8}\left[(\mathrm{M}+\mathrm{Na})^{+}\right]: 572.2003$, found: 572.2001 .

1,2-Dideoxy-1 $\beta$-[ $N$-(1-thyminylacetyl)aminomethyl]-D-ribose (4). To a solution of $3(20 \mathrm{mg}, 0.04 \mathrm{mmol})$ in $\mathrm{EtOH}(0.4 \mathrm{~mL})$ was added a solution of $\mathrm{KOH}(12 \mathrm{mg}, 0.21 \mathrm{mmol})$ in $\mathrm{EtOH}-\mathrm{H}_{2} \mathrm{O}(3: 1)(0.08$ $\mathrm{mL})$. The completion of the reaction was reached at $30 \mathrm{~min}$, a cation exchange resin (Dowex® 50WX8, hydrogen form) was added to the basic solution, in small increments, until neutrality according to $\mathrm{pH}$ paper. The suspension was filtered of, and the resin carefully washed with $\mathrm{EtOH}$. The crude was subjected to column chromatography $\left(5 \% \mathrm{MeOH} / \mathrm{CH}_{2} \mathrm{Cl}_{2}\right)$ to afford 4 as a white solid in $95 \%$ yield. $R_{\mathrm{f}}: 0.1\left(10 \% \mathrm{MeOH} / \mathrm{CH}_{2} \mathrm{Cl}_{2}\right) ; \mathrm{mp}: 133-135^{\circ} \mathrm{C}$; IR $(\mathrm{KBr}): \nu$ 3427, 2975, 2941, 2676, 1667, 1574, $1476 \mathrm{~cm}^{-1}$; UV $(\mathrm{MeOH}): \lambda(\max )=268 \mathrm{~nm}(\varepsilon 3100) ;{ }^{1} \mathrm{H}$ NMR $(300.13 \mathrm{MHz}, \mathrm{MeOH}-$ $\left.d_{4}\right): \delta 1.83\left(\mathrm{~m}, 2 \mathrm{H}, \mathrm{H}^{\prime}\right), 1.88$ (s, 3H, Me-C5), $3.38\left(\mathrm{~d}, 2 \mathrm{H}, \mathrm{H}^{\prime}, J_{\mathrm{HH}}\right.$ $4.8 \mathrm{~Hz}$ ), 3.53 (dd, $1 \mathrm{H}, \mathrm{H}^{\prime}, J_{\mathrm{HH}} 11.7,5.2 \mathrm{~Hz}$ ), 3.60 (dd, $1 \mathrm{H}, \mathrm{H}^{\prime}, J_{\mathrm{HH}}$ 11.7, $4.2 \mathrm{~Hz}$ ), 3.78 (q, $\left.1 \mathrm{H}, \mathrm{H} 4^{\prime}, J_{\mathrm{HH}} 4.3 \mathrm{~Hz}\right), 4.22\left(\mathrm{~m}, 2 \mathrm{H}, \mathrm{H}^{\prime}+\mathrm{H}^{\prime}\right)$, 4.40 (s, 2H, H7 $)$ ) 7.37 (d, 1H, H6, $\left.J_{\mathrm{HH}} 1.1 \mathrm{~Hz}\right) \mathrm{ppm} ;{ }^{13} \mathrm{C}$ NMR (75.5 $\left.\mathrm{MHz}, \mathrm{MeOH}-d_{4}\right): \delta 12.2(\mathrm{Me}), 38.8\left(\mathrm{C}^{\prime}\right), 44.1\left(\mathrm{C6}^{\prime}\right), 51.1\left(\mathrm{C}^{\prime}\right), 63.7$ $\left(\mathrm{C}^{\prime}\right), 73.7\left(\mathrm{C3}^{\prime}\right), 78.4\left(\mathrm{C1}^{\prime}\right), 88.7\left(\mathrm{C}^{\prime}\right), 111.0$ (C5), 143.7 (C6), 153.0 (C2), $167.0(\mathrm{C} 4), 169.8\left(\mathrm{O}=C-\mathrm{C}^{\prime}\right) \mathrm{ppm}$; HRMS $\left(\mathrm{ESI}^{+}, \mathrm{m} / \mathrm{z}\right)$ : calcd for $\mathrm{C}_{13} \mathrm{H}_{19} \mathrm{~N}_{3} \mathrm{NaO}_{6}\left[(\mathrm{M}+\mathrm{Na})^{+}\right]$: 336.1166, found: 336.1166.

1,2-Dideoxy-5-O-(4,4'-dimethoxytrityl)-1-[ $\mathrm{N}$-(1-thyminylacetyl)aminomethyl]-D-ribose (5, DMT-T*). To a solution of 4,4'dimethoxytrityl chloride $(81.3 \mathrm{mg}, 0.24 \mathrm{mmol})$ in anhydrous pyridine $(0.8 \mathrm{~mL})$ was added successively anhydrous $\mathrm{Et}_{3} \mathrm{~N}(46$ $\mu \mathrm{L}, 0.32 \mathrm{mmol})$ and $4(50 \mathrm{mg}, 0.16 \mathrm{mmol})$. The solution was heated at $45{ }^{\circ} \mathrm{C}$ during $5 \mathrm{~h}$. The solvent was evaporated and the residue was purified by column chromatography $(10 \% \mathrm{MeOH} /$ $\left.\mathrm{CH}_{2} \mathrm{Cl}_{2}\right)$ to afford 5 as a white solid in $69 \%$ yield. $R_{\mathrm{f}}: 0.45(10 \%$ $\mathrm{MeOH} / \mathrm{CH}_{2} \mathrm{Cl}_{2}$ ); mp: $107-109{ }^{\circ} \mathrm{C}$; IR (KBr): $\nu$ 3540, 3473, 3415, 2961, 2932, 1680, 1617, $1508 \mathrm{~cm}^{-1}$; ${ }^{1} \mathrm{H}$ NMR $(300.13 \mathrm{MHz}$, MeOH- $\left.d_{4}\right): \delta 1.77$ (s, 3H, Me-C5), $1.84\left(\mathrm{~m}, 2 \mathrm{H}, \mathrm{H} 2^{\prime}\right), 3.11(\mathrm{~d}, 2 \mathrm{H}$, $\mathrm{H}^{\prime}, J_{\mathrm{HH}} 4.9 \mathrm{~Hz}$ ), 3.29 (overlapped with $\mathrm{MeOH}-d_{4}, 1 \mathrm{H}, \mathrm{H}^{\prime}$ ), 3.46 (dd, 1H, H6' $J_{\mathrm{HH}} 14.0,7.1 \mathrm{~Hz}$ ), 3.74 (s, 6H, Me-DMT), 3.91 (m, $\left.1 \mathrm{H}, \mathrm{H} 4^{\prime}\right), 4.25\left(\mathrm{~m}, 4 \mathrm{H}, \mathrm{H} 1^{\prime}+\mathrm{H} 3^{\prime}+2 \mathrm{H}^{\prime}\right), 6.84\left(\mathrm{~d}, 4 \mathrm{H}, \mathrm{H}_{\text {arom }}, J_{\mathrm{HH}}\right.$ $8.9 \mathrm{~Hz}), 7.11$ (s, 1H, H6), 7.14-7.50 (m, 9H, $\left.\mathrm{H}_{\text {arom }}\right) ; \mathrm{ppm} ;{ }^{13} \mathrm{C}$ NMR (75.5 MHz, MeOH- $\left.d_{4}\right): \delta 12.2\left(\mathrm{CH}_{3}-\mathrm{C} 5\right), 39.1\left(\mathrm{C}^{\prime}\right), 44.4$ $\left(\mathrm{C6}^{\prime}\right), 51.0\left(\mathrm{C}^{\prime}\right), 55.7\left(2 \mathrm{O}-\mathrm{CH}_{3}\right), 65.7\left(\mathrm{C}^{\prime}\right), 74.5\left(\mathrm{C}^{\prime}\right), 78.5\left(\mathrm{C}^{\prime}\right)$, 87.4 (C-DMT), 87.7 (C4'), 110.9 (C5), 114.1 (4CH $\left.\mathrm{CHom}_{\text {arom }}\right), 127.8$ ( $\left.\mathrm{CH}_{\text {arom }}\right), 128.8\left(2 \mathrm{CH}_{\text {arom }}\right), 129.4\left(2 \mathrm{CH}_{\text {arom }}\right), 131.3\left(4 \mathrm{CH}_{\text {arom }}\right)$, 137.3 (2C $\mathrm{C}_{\text {ipso }}$ ), $143.6(\mathrm{C} 6), 146.5$ ( $\left.\mathrm{C}_{\text {ipso }}\right), 152.9(\mathrm{C} 2), 160.1\left(2 \mathrm{C}_{\text {ipso }}\right)$, 167.0 (C4), $169.5\left(\mathrm{O}=C\right.$-C7) ppm; HRMS (ESI $\left.{ }^{+}, m / z\right)$ : calcd for $\mathrm{C}_{34} \mathrm{H}_{37} \mathrm{~N}_{3} \mathrm{NaO}_{8}\left[(\mathrm{M}+\mathrm{Na})^{+}\right]:$638.2473, found: 638.2474 .

DMT-T* phosphoramidite derivative (6). Compound 5 (150 $\mathrm{mg}, 0.24 \mathrm{mmol}$ ) was dried by evaporation with anhydrous MeCN $(\times 2)$ under reduced pressure and left in a desiccator for
$30 \mathrm{~min}$. Next the product was dissolved in anhydrous $\mathrm{CH}_{2} \mathrm{Cl}_{2}(10$ $\mathrm{mL})$ under argon and ${ }^{\mathrm{i}} \mathrm{Pr}_{2} \mathrm{NEt}(230 \mu \mathrm{L}, 1.32 \mathrm{mmol})$ was added with exclusion of moisture. The solution was cooled and 2-cyanoethoxy- $N, N^{\prime}$-diisopropylaminochlorophosphine $(114 \mu \mathrm{L}$, $0.48 \mathrm{mmol}$ ) was added dropwise with a syringe. Afterwards, the solution was stirred at room temperature for $1 \mathrm{~h}$. Then $15 \mathrm{~mL}$ of $\mathrm{CH}_{2} \mathrm{Cl}_{2}$ were added to the reaction mixture and the organic phase was washed with saturated aqueous $\mathrm{NaCl}(15 \mathrm{~mL})$. After drying the organic phase with $\mathrm{MgSO}_{4}$, the solvent was evaporated under reduced pressure and the product was purified by column chromatography. The column was packed with silica gel using a $10 \% \mathrm{Et}_{3} \mathrm{~N}$ solution in EtOAc/hexane $1: 1$ and the gradient used was from EtOAc/hexane $1: 1$ to pure EtOAc. After the chromatography, a white solid was obtained (198 mg, 85\% yield). $R_{\mathrm{f}}($ EtOAc $)=0.36$ and $0.30 .{ }^{31} \mathrm{P} \mathrm{NMR}\left(162 \mathrm{MHz}, \mathrm{Cl}_{3}\right)$ : $\delta 148.02$ and 147.92; HRMS (ESI $\left.{ }^{+}, m / z\right)$ : calcd for $\mathrm{C}_{43} \mathrm{H}_{55} \mathrm{~N}_{5} \mathrm{O}_{9} \mathrm{P}$ $\left[(\mathrm{M}+\mathrm{H})^{+}\right]$: 816.3732, found: 816.3706; calcd for $\mathrm{C}_{43} \mathrm{H}_{54} \mathrm{~N}_{5} \mathrm{NaO}_{9} \mathrm{P}$ $\left[(\mathrm{M}+\mathrm{Na})^{+}\right]:$838.3551, found: 838.3527 .

DMT-T* hemisuccinate derivative (7). The DMT derivative 5 (50 $\mathrm{mg}, 0.08 \mathrm{mmol}$ ) was dried by evaporation with anhydrous MeCN $(\times 2)$ under reduced pressure and left in a desiccator for $30 \mathrm{~min}$. Once dried, the compound was dissolved in anhydrous $\mathrm{CH}_{2} \mathrm{Cl}_{2}(5 \mathrm{~mL})$ under argon. Succinic anhydride $(11 \mathrm{mg}, 0.11$ mmol) and DMAP (13 $\mathrm{mg}, 0.11 \mathrm{mmol}$ ) were added and the solution was stirred overnight at room temperature. Then 15 $\mathrm{mL}$ of $\mathrm{CH}_{2} \mathrm{Cl}_{2}$ were added and the solution was washed with $0.1 \mathrm{M} \mathrm{H}_{2} \mathrm{NaPO}_{4}$ and saturated aqueous $\mathrm{NaCl}(2 \times 20 \mathrm{~mL})$. The organic layer was dried over anhydrous $\mathrm{MgSO}_{4}$, filtered and evaporated to dryness. The resulting hemisuccinate 7 was obtained as a white solid ( $46 \mathrm{mg}, 79 \%$ yield) and was used in the next step without further purification. $R_{\mathrm{f}}\left(\mathrm{CH}_{2} \mathrm{Cl}_{2} / \mathrm{MeOH}\right.$, $10: 0.5)=0.20$.

Functionalization of controlled pore glass with succinyl DMT-T* Preparation of (8). The hemisuccinate derivative 7 prepared above was incorporated on a long-chain alkylaminecontrolled pore glass support (LCAA-CPG). Amino-LCAA-CPG (CPG New Jersey; $150 \mathrm{mg}, 73 \mu \mathrm{mol}$ amino per g) was placed into a polypropylene syringe fitted with a polypropylene disc and washed sequentially with $\mathrm{MeOH}, \mathrm{CH}_{2} \mathrm{Cl}_{2}$ and $\mathrm{MeCN}$ $(2 \times 5 \mathrm{~mL})$ and dried under vacuum. Then 2,2'-dithio-bis(5nitropyridine) (DTNP) $(20 \mathrm{mg}, 0.06 \mathrm{mmol})$ dissolved in $200 \mu \mathrm{L}$ of a mixture of $\mathrm{MeCN} / \mathrm{CH}_{2} \mathrm{Cl}_{2}(1: 3)$ was added to a solution of 7 (23 mg, $0.03 \mathrm{mmol}$ ) and DMAP ( $8 \mathrm{mg}, 0.06 \mathrm{mmol}$ ) in MeCN (500 $\mu \mathrm{L})$. Next, $\mathrm{Ph}_{3} \mathrm{P}(17 \mathrm{mg}, 0.06 \mathrm{mmol})$ was added. The mixture was vortexed for a few seconds and added to the support and allowed to react for $1 \mathrm{~h}$. The support was washed with $\mathrm{MeOH}$, $\mathrm{CH}_{2} \mathrm{Cl}_{2}$ and $\mathrm{MeCN}(2 \times 5 \mathrm{~mL})$ and dried under vacuum. The functionality of the resin was determined by DMT quantification $\left(44.3 \mu \mathrm{mol} \mathrm{g}^{-1}\right)$. Finally, the solid support was treated with a mixture of $\mathrm{Ac}_{2} \mathrm{O} / \mathrm{DMF}(1: 1,500 \mu \mathrm{L})$ during 30 min to cap free amino groups.

\section{Oligonucleotide synthesis and purification}

Oligonucleotides used in this study are summarized in Table 1. Modified oligonucleotides $15 \mathrm{Mer}_{-} \mathrm{T}^{*}(01)$, (02) and (03) were prepared on a DNA synthesizer (Applied Biosystems 3400, 
Foster City, CA, USA) using $200 \mathrm{nmol}$ scale LV200® polystyrene supports, the $\mathrm{T}^{*}$ phosphoramidite described above and commercially available chemicals. In all cases the coupling yields of the modified phosphoramidite were $>97 \%$. The unmodified oligonucleotides were synthesized following standard protocols or purchased. The last DMT was left at the end of the synthesis. Then, the resulting supports were treated with aqueous concentrated ammonia at room temperature for $12 \mathrm{~h}$ and $1 \mathrm{~h}$ at $55{ }^{\circ} \mathrm{C}$ to cleave the products from the supports and remove the $\mathrm{Bz}$ and $\mathrm{Ibu}$ groups. The oligonucleotides were purified by cartridge (Glen-Pak ${ }^{\mathrm{TM}}$ DNA purification cartridge) from Glen Research. Then, they were desalted with Sephadex G25 (IllustraNAP-10 or NAP-5 columns, from GE Healthcare Life Sciences). Finally, they were analyzed by mass spectrometry (MALDI-TOF) and HPLC. Solvent A: 5\% MeCN in $100 \mathrm{mM}$ triethylammonium acetate (TEAA) (pH 7) and solvent B: 70\% MeCN in $100 \mathrm{mM}$ TEAA (pH 7). Column: XBridgeTM OST C18 column;

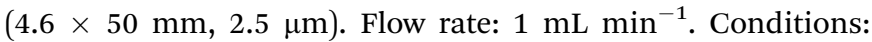
$10 \mathrm{~min}$ of linear gradient from 0 to $20 \%$ of $\mathrm{B}$, for modified 15Mer's.

For the synthesis of modified RNA, a solid support carrying 2 units of $\mathrm{T}^{*}$ was synthesized on a $1 \mu \mathrm{mol}$ scale using the modified solid support and the appropriate phosphoramidite. Then the rest of the RNA sequence was assembled using standard RNA synthesis protocols and tert-butyldimethylsilyl (TBDMS) protected RNA monomers $\left(\mathrm{A}^{\mathrm{Bz}}, \mathrm{G}^{\mathrm{dmf}}, \mathrm{C}^{\mathrm{Ac}}\right.$ and $\left.\mathrm{U}\right)$ on $0.2 \mu \mathrm{mol}$ scale as described. ${ }^{13}$ The following solutions were used: $0.4 \mathrm{M}$ $1 \mathrm{H}$-tetrazole in $\mathrm{MeCN}$ (activation); $3 \% \mathrm{Cl}_{3} \mathrm{CCO}_{2} \mathrm{H}$ in $\mathrm{CH}_{2} \mathrm{Cl}_{2}$ (detritylation), $\mathrm{Ac}_{2} \mathrm{O} / \mathrm{Py} / \mathrm{THF}(1: 1: 8$ ) (capping A), $10 \% \mathrm{~N}$ methylimidazole in THF (capping $\mathrm{B}$ ), $0.01 \mathrm{M}$ iodine in THF/Py/ $\mathrm{H}_{2} \mathrm{O}(7: 2: 1)$ for the oxidation step. The coupling time was 15 min. All oligonucleotides were synthesized in DMT-ON mode. After the solid-phase synthesis, the solid support was transferred to a screw-cap glass vial and incubated at $55{ }^{\circ} \mathrm{C}$ for $1 \mathrm{~h}$ with $1.5 \mathrm{~mL}$ of $\mathrm{NH}_{3}$ solution (33\%) and $0.5 \mathrm{~mL}$ of EtOH. The vial was then cooled on ice and the supernatant was transferred into a $2 \mathrm{~mL}$ eppendorf tube. The solid support and vial were rinsed with $50 \%$ EtOH $(2 \times 0.25 \mathrm{~mL})$. The combined solutions were evaporated to dryness using an evaporating centrifuge. The residue that was obtained was dissolved with $0.15 \mathrm{~mL}$ of triethylamine tris(hydrofluoride) $/ \mathrm{Et}_{3} \mathrm{~N} / \mathrm{N}$-methylpyrrolidone ( $4: 3: 6$ ) for $2.5 \mathrm{~h}$ at $65{ }^{\circ} \mathrm{C}$ to remove the TBDMS groups. Oligonucleotides were purified using oligonucleotide purification cartridge (Glen Research) and HPLC. Yields ( $0.2 \mu \mathrm{mol}$ scale synthesis) were between 10 and 15 OD units at $260 \mathrm{~nm}$.

\section{Denaturation studies}

Melting experiments were performed using a Jasco V-650 instrument equipped with a thermoregulated cell holder. They were performed in duplicate at $3 \mu \mathrm{M}$ concentration of oligonucleotide. The samples were prepared using a solution $50 \mathrm{mM}$ $\mathrm{NaCl}$ and $10 \mathrm{mM}$ sodium phosphate buffer ( $\mathrm{pH}$ 7.0). Concentrations of all oligonucleotides were estimated by UV-Vis absorption at $50{ }^{\circ} \mathrm{C}$ using the $\varepsilon_{260}$ values calculated by the nearest-neighbor method for the DNA coil state. The samples were heated at $90{ }^{\circ} \mathrm{C}$ for $5 \mathrm{~min}$, allowed to cool slowly to room temperature and kept overnight in a refrigerator. The melting curves were recorded monitoring the absorbance at $260 \mathrm{~nm}$. The samples were heated with a temperature controller from $10^{\circ} \mathrm{C}$ to $75-80{ }^{\circ} \mathrm{C}$ at a constant rate of $1{ }^{\circ} \mathrm{C} \mathrm{min}{ }^{-1}$ using $1 \mathrm{~cm}$ quartz pathlength cuvettes with a ground hole at the top to adapt a PTFE stopper to provide a suitable seal to avoid evaporation during the acquisition. When the temperature was below $25^{\circ} \mathrm{C}$ nitrogen was flushed to prevent water condensation. At least two different samples were prepared for each melting experiment. Thermodynamic data were calculated from the melting curves by computer fitting using the Meltwin 3.5 software.

\section{Cells}

HeLa cells (ATCC) were maintained in monolayer culture at exponential growth in high-glucose Dulbecco modified Eagle medium (DMEM) (Gibco, Life Technologies, Carlsbad, CA, USA) supplemented with $10 \%$ heat inactivated fetal bovine serum (Gibco, Life Technologies, Carlsbad, CA, USA) and $1 \times$ penicillin/streptomycin solution (Gibco, Life Technologies, Carlsbad, CA, USA). Cells were incubated at $37{ }^{\circ} \mathrm{C}$ in a humidified environment with $5 \% \mathrm{CO}_{2}$ and periodically checked for the presence of mycoplasma contamination. Cell viability was monitored by Trypan Blue exclusion assay and was higher than $95 \%$ in all experiments.

\section{Transfection and luciferase assay}

For siRNA luciferase assay, HeLa cells were plated in 24-well tissue culture plates at density of $1 \times 10^{5}$ cells per well $24 \mathrm{~h}$ before transfection. In dose response, ON-/OFF-target assessment $1 \mu \mathrm{g}$ of psiCHECK2 (AS) or psiCHECK2 and siRNAs at different concentrations were co-transfected using Lipofectamine 2000 (Life Technologies, Carlsbad, CA, USA) in accordance with the manufacturer's instructions. The inhibitory effect of siRNAs on Renilla protein expression was measured on lysates collected $24 \mathrm{~h}$ after transfection using the DualLuciferase Reporter Assay System (Promega Biotech Iberica, Madrid, Spain) and a GloMax Discover luminometer (Promega Biotech Iberica, Madrid, Spain). The ratios of Renilla luciferase (hRluc) to Photinus luciferase (hluc+) protein activities were normalized to mock transfection and the mock activity was set as $100 \%$. Statistical analysis was performed using GraphPad Prism software (GraphPad, San Diego, CA, USA). IC $_{50}$ determination was performed using non-linear regression analysis (log[inhibitor] vs. normalized response).

\section{Acknowledgements}

Financial support by the Spanish Ministerio de Ciencia e Innovación (MICINN) (Projects CTQ2011-24237, CTQ201455015-P, and CTQ2014-52588-R) and Principado de Asturias (Project FC-15-GRUPIN14-002) are gratefully acknowledged. CIBER-BBN is an initiative funded by the VI National $\mathrm{R}+\mathrm{D}+\mathrm{i}$ Plan 2008-2011, Iniciativa Ingenio 2010, Consolider Program, CIBER Actions and financed by the Instituto de Salud Carlos III with assistance from the European Regional Development Fund. 


\section{References}

1 Y. S. Sanghvi, Chem. Today, 2014, 32, 10-15.

2 Y. S. Sanghvi, in Current Protocols in Nucleic Acid Chemistry, ed. M. Egli, P. Herdewijn, A. Matsuda and Y. S. Sanghvi, 2011, pp. 4.1.1-4.1.22.

3 Y. S. Sanghvi, Future Science, 2013, 6-22.

4 B. Hyrup and P. E. Nielsen, Bioorg. Med. Chem., 1996, 4, 5-23.

5 J. S. Jepsen, M. D. Sørensen and J. Wengel, Oligonucleotides, 2004, 14, 130-146.

6 D. D'Alonzo, A. Van Aerschot, A. Guaragna, G. Palumbo, G. Schepers, S. Capone, J. Rozenski and P. Herdewijn, Chem.-Eur. J., 2009, 15, 10121-10131.

7 M. Bolli, H. U. Trafelet and C. Leumann, Nucleic Acids Res., 1996, 24, 4660-46607.

8 C. J. Wilds and M. J. Damha, Bioconjugate Chem., 1999, 10, 299-305.

9 N. Martín-Pintado, M. Yahyaee-Anzahaee, R. Campos-Olivas, A. M. Noronha, C. J. Wilds, M. J. Damha and C. González, Nucleic Acids Res., 2012, 40, 9329-9339.
10 M. A. Campbell and J. Wengel, Chem. Soc. Rev., 2011, 40, 5680-5689.

11 K. Murayama, H. Kashida and H. Asanuma, Chem. Commun., 2015, 51, 6500-6503.

12 Y. Kamiya, J. Takai, H. Ito, K. Murayama, H. Kashida and H. Asanuma, ChemBioChem, 2014, 15, 2549-2555.

13 A. Alagia, M. Terrazas and R. Eritja, Molecules, 2014, 19, 17872-17896.

14 A. Alagia, M. Terrazas and R. Eritja, Molecules, 2015, 20, 7602-7619.

15 C. L. Scremin, J. H. Boal, A. Wilk, L. R. Phillips and S. L. Beaucage, Bioorg. Med. Chem. Lett., 1996, 6, 207212.

16 J. H. Boal, A. Wilk, C. L. Scremin, G. N. Gray, L. R. Phillips and S. L. Beaucage, J. Org. Chem., 1996, 61, 8617-8626.

17 J. Robles, A. Grandas, E. Pedroso, F. J. Luque, R. Eritja and M. Orozco, Curr. Org. Chem., 2002, 6, 1333-1368.

18 Pure $\beta$-cyano-sugar 1 is available from Sapala Organics Pvt. Ltd., India (http://www.sapalaorganics.com). 